\title{
Stability Evaluation of Immobilized Peptides Towards Proteases by Mass Spectrometry
}

\author{
Silvana L. Giudicessi ${ }^{1}$, María L. Salum², María C. Martínez-Ceron ${ }^{1}$, \\ Osvaldo Cascone ${ }^{1}$, Rosa Erra-Balsells ${ }^{2}$, and Silvia A. Camperi ${ }^{1 *}$ \\ ${ }^{I}$ NANOBIOTEC Institute, UBA-CONICET, Cathedra of Biotechnology, School of Pharmacy and Biochemistry, \\ UBA, Junín 956, 1113, Buenos Aires, Argentina ${ }^{2}$ CIHIDECAR-CONICET, Dept. of Organic Chemistry, \\ School of Exact and Natural Sciences, UBA, 1428, Buenos Aires, Argentina \\ *scamperi@ffyb.uba.ar
}

\section{Introduction}

Short peptides are widely used as ligands in affinity chromatography purification of proteins [1,2]. However, peptidases and proteases present in the crude sample may degrade immobilized peptides, shortening the affinity support useful life. Then, peptide ligand stability must be evaluated before its use in a purification process. Commonly, enzymatic stability is evaluated with the peptide in solution, which may differ from the resin-bound peptide behavior [3]. Further, as the peptides to be evaluated are in solution in the reaction mixture, the study of the peptide degradation products requires purification steps before their analysis [4].

In this work we developed a strategy to evaluate immobilized peptide stability using electrospray ionization (ESI) and matrix assisted laser desorption/ionization (MALDI) mass spectrometry (MS).

\section{Results and Discussion}

ChemMatrix (CM) was used as the solid support due to its chemical stability. This PEG-based matrix allowed peptide synthesis in organic solvents and stability peptide evaluation in aqueous solvents [5]. 4-Hydroxymethylbenzoic acid (HMBA) [6] was used as the linker in order to introduce a cleavage site to release the peptides from the beads before MS analysis. The model peptide H-Phe-Lys-Phe-ArgTyr-Thr-Ala-His-Ser-Gly-Ala-Ser-Gly- $\mathrm{NH}_{2}$ with known trypsin and chymotrypsin cleavage sites [7] was synthesized on HMBA-CM resin $(0.63 \mathrm{mmol} / \mathrm{g})$ by using the Fmoc strategy as we have previously described [1]. Ser-Gly-Ala-Ser-Gly was incorporated as a spacer arm at the $C$-terminal. After peptide elongation, protecting groups were removed with trifluoroacetic acid (TFA)/triisopropylsilane (TIS) $/ \mathrm{H}_{2} \mathrm{O}(95: 2.5: 2.5 \mathrm{v} / \mathrm{v} / \mathrm{v})$, leaving the unprotected peptides anchored to the resin. Peptide beads were washed with dichloromethane (DCM), N,N-dimethylformamide (DMF), $\mathrm{H}_{2} \mathrm{O}: \mathrm{DMF}(3: 7 ; 5: 5 ; 7: 3 \mathrm{v} / \mathrm{v}$ )

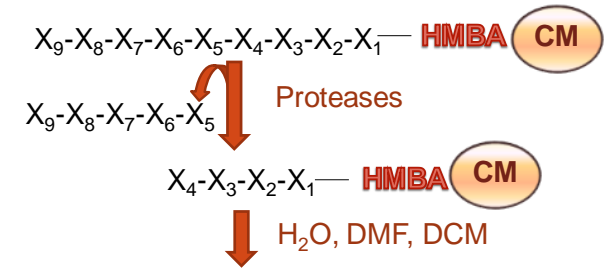

Impurities removed by solid phase wash

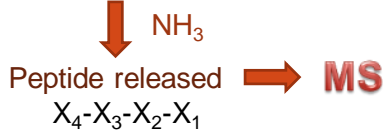

Fig. 1. Strategy for immobilized peptide stability evaluation. and $\mathrm{H}_{2} \mathrm{O}$. Then, $0.1 \mathrm{mg}$ of peptidyl-resin (approximately 100 peptidyl-beads) was incubated with solution A (trypsin $40 \mu \mathrm{M}$ in Tris- $\mathrm{HCl} 40 \mathrm{mM}$, $\mathrm{pH} 8.1, \mathrm{CaCl}_{2} 10 \mathrm{mM}$ buffer) or B (chymotrypsin 40 $\mu \mathrm{M}$ in Tris- $\mathrm{HCl} 40 \mathrm{mM}, \mathrm{pH} 8.1, \mathrm{CaCl}_{2} 10 \mathrm{mM}$ buffer) overnight. The peptidyl-beads were then thoroughly washed with $\mathrm{H}_{2} \mathrm{O}, \mathrm{H}_{2} \mathrm{O}$ :DMF $(7: 3 ; 5: 5$; 3:7 v/v), DMF and DCM. Later on, peptides were detached with ammonia vapor. Released peptides were eluted by adding acetic acid/acetonitrile $\left(\mathrm{CH}_{3} \mathrm{CN}\right) / \mathrm{H}_{2} \mathrm{O}(3: 4: 3 \mathrm{v} / \mathrm{v} / \mathrm{v})$ (Figure 1). Eluted peptides were analyzed by mass spectrometry (MS). ESI mass spectra were recorder in a Bruker microTOF-Q II (Bruker Daltonics GmbH, Leipzig, Germany). $5 \mu \mathrm{L}$ aliquot of eluted peptide was injected and analyzed in positive mode. MALDI mass spectra were recorded in an Ultraflex II TOF/TOF (Bruker Daltonics GmbH, Leipzig, Germany). $1 \mu \mathrm{L}$ Aliquot of eluted peptide from 100 beads was loaded onto the sample plate, air-dried at room temperature, and then $1 \mu \mathrm{L}$ of MALDI matrix solution was added on the sample dry layer (successive-dry-layers deposit method). Two matrices solutions were assayed: a) Commercial E- $\alpha$-cyano-4-hydroxycinnamic acid (CHCA) 4 
$\mathrm{mg} / \mathrm{mL}$ in $\mathrm{CH}_{3} \mathrm{CN} / \mathrm{H}_{2} \mathrm{O}(1: 1 \mathrm{v} / \mathrm{v})$ with $0.1 \%$ TFA and b) Z-sinapinic acid (SA) $[8,9] 5 \mathrm{mg} / \mathrm{mL}$ in $\mathrm{MeOH} / \mathrm{H}_{2} \mathrm{O}(7: 3 \mathrm{v} / \mathrm{v})$. Mass spectra were acquired in the MS reflectron positive ion mode.

Figure 2 shows the ESI mass spectra obtained before and after subjecting the peptide-beads with chymotrypsin and trypsin. ESI-MS allowed the detection of the whole peptides (Figure 2 A) as well as their $C$-terminal enzymatic degradation products (Figures $1 \mathrm{~B}$ and $\mathrm{C}$ ) obtained after incubation with trypsin and chymotrypsin.

When analyzing the peptide and their degradation products with MALDI-MS, E- $\alpha$-cyano-4hydroxycinnamic acid matrix clusters interfered in MALDI-MS analysis of low molecular weight products. On the other hand, Z-sinapinic acid matrix allowed their analysis (Figures $1 \mathrm{D}$ and E).

The method here developed allowed a fast evaluation of peptide ligands stability in solid phase towards the proteases that may be present in the crude sample before their use in affinity chromatography. Due to the high sensitive of mass spectrometry, only a small sample of peptidyl-resin is required to evaluate its stability. As the enzymatic degradation is performed in solid-phase, none hard purification protocols are needed before analysis.
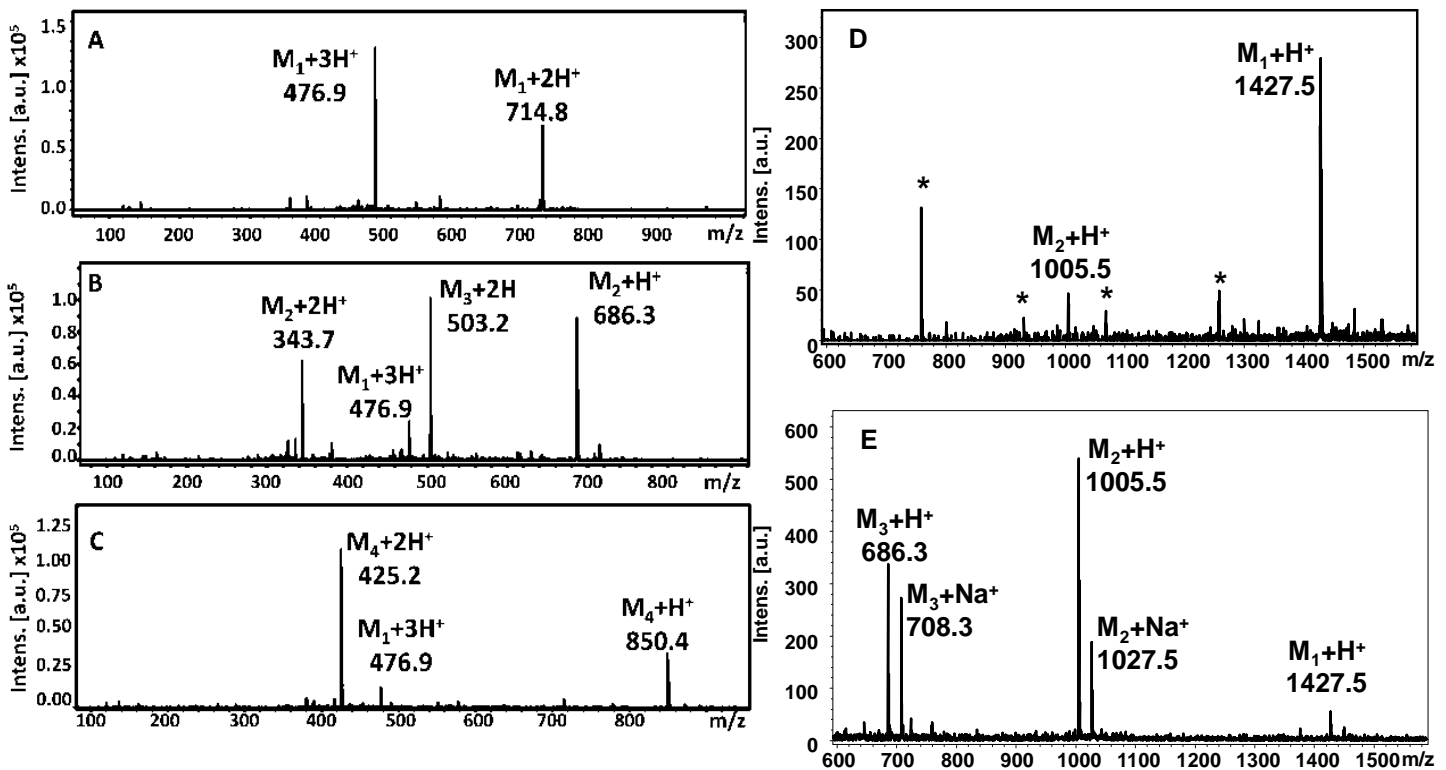

Fig. 2. ESI mass spectra of peptide H-Phe-Lys-Phe-Arg-Tyr-Thr-Ala-His-SerGly-Ala-Ser-Gly-NH before $(A)$ and after treatment with chymotrypsin $(B)$ and trypsin $(C)$. The signals at $\mathrm{m} / \mathrm{z} 476.9$ and 714.8 correspond to the whole peptide FKFRYTAHSGASG $\left[\mathrm{M}+3 \mathrm{H}^{+}\right]$and $\left[\mathrm{M}+2 \mathrm{H}^{+}\right]$respectively. The signals at $\mathrm{m} / z, 343.7$ and 686.3 correspond to the degradation product TAHSGASG $\left[\mathrm{M}_{2}+2 \mathrm{H}^{+}\right]$and $\left[\mathrm{M}_{2}+\mathrm{H}^{+}\right]$respectively and 503.2 correspond to the degradation product RYTAHSGASG $\left[\mathrm{M}_{3}+2 \mathrm{H}^{+}\right]$. The signals at $\mathrm{m} / \mathrm{z} 425.2$ and 850.4 correspond to the degradation product YTAHSGASG $\left[\mathrm{M}_{4}+2 \mathrm{H}^{+}\right]$ and $\left[M_{4}+H^{+}\right]$. MALDI mass spectra of peptide FKFRYTAHSGASG after treatment with chymotrypsin using $\alpha$-cyano-4-hydroxycinnamic acid matrix $(D)$ or using $Z$-sinapinic acid matrix $(E)$. The signal at $\mathrm{m} / \mathrm{z}$ 1427.5 corresponds to the whole peptide FKFRYTAHSGASG $\left[M+\mathrm{H}^{+}\right]$. The signals at $\mathrm{m} / \mathrm{z} 1005.5$ and 1027.5 correspond to the degradation product RYTAHSGASG $\left[\mathrm{M}_{2}+\mathrm{H}^{+}\right]$and $\left[\mathrm{M}_{2}+\mathrm{Na}^{+}\right]$ respectively. The signals at $\mathrm{m} / \mathrm{z} 686.3$ and 708.3 correspond to the degradation product TAHSGASG $\left[\mathrm{M}_{3}+\mathrm{H}^{+}\right]$and $\left[\mathrm{M}_{3}+\mathrm{Na}^{+}\right]$respectively. The signals marked with an asterisk (*) correspond to the matrix matrices clusters. 


\section{Acknowledgments}

This work was partially supported by the National Scientific and Technological Research Council (Consejo Nacional de Investigaciones Científicas y Técnicas de la República Argentina) (CONICET), PIP 11220130100119CO, the University of Buenos Aires (20020130100060BA and PB03-PDTS-PCTI-74). S.L.G, M.L.S, M.C.M.C, O.C., R.E.B. and S.A.C. are researchers of the CONICET. We thank Simon Côté from Matrix Innovation Inc. for a generous donation of HMBA-ChemMatrix resin.

\section{References}

1. Camperi, S.A., et al. in Labrou, N. (Ed.) Methods in Molecular Biology: Protein Downstream Processing, Humana Press Inc. Springer, New York, 2014, Vol 1129, p. 277-302, http://dx.doi.org/10.1007/978-1-62703977-2_22

2. Huang, P.Y., Carbonell, R.G. Biotechnol. Bioeng. 47, 288-297 (1995), http://dx.doi.org/10.1002/bit.260470303

3. Bell, L.N. Biotechnol. Prog. 13, 342-346 (1997), http://dx.doi.org/10.1021/bp970057y

4. Knör, S.A., et al. J. Thromb Haemost. 6, 470-477 (2008), http://dx.doi.org/10.1111/j.1538-7836.2008.02893.x

5. Camperi, S.A., et al. Tetrahedron Lett. 46, 1561-1564 (2005), http://dx.doi.org/10.1016/j.tetlet.2004.12.105

6. Atherton, E., et al. J. Chem. Soc. Perkin Trans. 1, 538-546 (1981), http://dx.doi.org/10.1039/P19810000538

7. Sweeney, P.J. and Walker, J. M. in: Michael, M.B. (Ed.), Methods in Molecular Biology: Enzymes of

Molecular Biology, Humana Press Inc. Springer, New York, 2014, Vol 16, p. 277-303,

http://dx.doi.org/10.1385/0896032345

8. Salum, M.L., et al. Org. Lett. 12, 4808-4811 (2010), http://dx.doi.org/10.1021/ol1019508

9. Salum, M.L., et al. Application of Z-sinapinic matrix in short peptide MALDI-MS analysis. Manuscript under preparation. 